\title{
Survey of health informatics education in Finland in 2017
}

\author{
Johanna Tolonen, M.Sc., Alpo Värri, Dr.Tech.
}

Tampere University of Technology, Tampere, Finland

\begin{abstract}
Johanna Tolonen, MSc, Faculty of Biomedical Sciences and Engineering, Tampere University of Technology, P.O.
\end{abstract} Box 553, FI-33101 Tampere, FINLAND. Email: Johanna.Tolonen@tut.fi

\begin{abstract}
The European Union and the USA collaborate in developing the skills of the application of information technology in the health care workforce. A part of this activity is a project which studies the gaps in the present education and proposes methods of filling these gaps. The objective of this paper is to identify the existing IT related education to the health care work force in Finland. A secondary objective was to get an impression of the experience and attitudes of the members of this workforce about health IT education.
\end{abstract}

This paper presents the results of the survey of how information technology is educated to the students of the health care professions in Finland in the year 2017. In addition to literature search including also the study guides of many major health care professional education organizations, 24 telephone interviews of health care professionals in different fields in Finland were made.

The results show that although basic information technology education is often available at every level of education, it is expected that the health care professionals learn to use the health information systems during their training periods or later in working life. The interviews showed that the given education varied considerably and some of the personnel had received no or only a little education on IT during studies. As the amount and quality of onthe-job information technology education varies, many health care professionals are not able to fully benefit from the information systems if their general feeling is that they just "survive" from daily activities with them.

The results lead to suggest that the health professional degrees should contain at least a minimal amount of relevant health IT education which is tested with an exam and that the present health care workforce should receive ear-marked in-service training in the use of health information technology based on the needs of the individual.

Keywords: health informatics competency, health informatics skills, health informatics workforce, health informatics education, health information technology

\section{Introduction}

Information systems in health care are complex, and therefore their users should be taught to use them according to the role of the user [1]. In Europe, there has been development in the health IT education throughout the years and by different organizations (for example with the support of the European Commission). Some of the initiatives have been meant for the education of the health care personnel and some for a whole degree. The education of health IT should also be targeted for the specific user group. For example, doc- 
tors need only superficial knowledge about the systems but they need more practical knowledge of the use of the systems [2].

There have been several projects for developing health informatics education in European Union (EU) area. The first guideline was published as a result of an EUEDUCTRA (1995) project [3]. The follow-up project was IT-EDUCTRA and it provided an educational CD as an end product as well as new curricula and guidelines for the education of health IT $[4,5]$. The NIGHTINGALE project (1998) aimed to apply health informatics education in nursing education [6].

A study of health IT education was conducted in the United Kingdom (UK) in 2004 [7]. Before the study it was noticed that there was confusion who is responsible for the IT and health IT education; pre- and postgraduate educational providers or employers. There was lack of co-operation and co-ordination of the education. The results of the study suggested that health informatics had not yet been integrated into every clinical curriculum, but there was some kind of IT education provided by the educational institutes, even though it was considered insufficient. Also the amount of education varied considerably. The study showed that most of the educational institutes (in nursing and medicine) provided some IT education, but there were large differences in the amount of teaching and areas covered. IT skills were not evaluated formally. The graduates lacked IT skills and it was found that it was their responsibility to educate themselves. [7]

Learning to Manage Health Information (LtMHI) is a guideline by the National Health Service in the UK (2012). It is targeted for institutes providing clinical education and for integrating IT education in their curricula. In the curricula there are seven main themes which cover areas from health care records to eHealth. There are learning outcomes classified at three levels according to the graduation (under- and postgraduate, management). [8]

After these projects and the development of the educational programs, the International Medical Informatics Association (IMIA) started regularly revising recom- mendations for health IT education. The latest IMIA recommendation was updated in the year 2010, where educational needs were defined in detail, recommendations were given to the establishment of courses and course tracks and the certification of high quality Biomedical and Health Informatics education was initiated. [9]. In Finland, there is for example, a master's program in health informatics in the University of Eastern Finland. This program is intended for all health professional groups who have a sufficient basic degree. Its duration is two years. [10]

The newest development in the field has been the project that defined the health information competencies in the USA and European Union (EU). In this transatlantic project, a tool was developed for defining the professional roles in health care [11]. The HITCOMP tool contains 268 definitions of professional roles that were divided into eight domains. The $1000+$ skills related to health IT were defined at four levels of expertise [12].

There is still lack of well trained professionals in health IT who know how to benefit from the systems in order to improve the quality of care and reduce costs [2]. The EU*US eHealth Work project [11] continues to promote the development of the skills of the health care workforce in applying information technology. A part of the project is to study the gaps in the present education and to propose methods of filling these gaps. The objective of this paper is to identify the existing IT related education to the health care work force in Finland. There are plenty of stakeholders in the field in the health care area. In this paper, the focus is narrowed to the health care personnel that are working next to the patient i.e. to medical doctors, registered nurses and practical nurses. A secondary objective was to get an impression of the experience and attitudes of these groups about health IT education.

Education for health care personnel in Finland is provided in secondary schools (practical nurses), the universities of applied sciences (registered nurses) and universities (medical doctors and pharmacists BSc). For the education given at the universities of applied sciences, there is a law and regulations of the general contents of the education [13-15] as there is a law for 
university studies [16]. Still, the universities have a lot of freedom defining the content of the education of the health care personnel. There was a development project in trying to unify the nursing education curricula in Finland in 2015 [17]. The developed guideline included also recommendations on the health IT education. The developed curriculum bases on the European Union Directive 2015/55/EU on the recognition of professional qualifications (2013/55/EU). The practical nursing education is defined in more detail by the Finnish National Board of Education [18].

Those health care professionals who have passed an accredited health professional degree in applicable universities and vocational schools Finland, are entered to a publicly available health care professional database maintained by the National Supervisory Authority for Welfare and Health (Valvira). Physicians, pharmacists, nurses, public health nurses are licensed professionals, and the practice is restricted for these professionals only. Practical nurse for social and health care is a protected occupational title. The difference between licensed and protected titles is that practical nursing work can be practiced also by a person with required professional skills, without using the title. [19]

The municipalities must organize supplementary education for the health care personnel and the employers must fund it. The recommended amount of education suggested by the trade union of the practical nurses Super is 3-10 days per year. The supplementary education is intended to develop the care quality, care practices and efficiency. It also benefits the well-being of the workers and helps the workers to continue their career till they retire. $[20,21]$

This article has two parts. The first part is a literature review of the contents of information technology education in the health professional degrees in Finland. The literature research covers the five universities that provide the education of the medical doctors, the universities of applied sciences in nine major institutes that offer education for the degree of a registered nurse and practical nurse education in general. A survey is also made about the existing continuing education in health IT to the graduated health care professionals. The sec- ond part is an interview to 24 health care professionals about the education they have received in IT and what are their experiences about it. The report from the interviews also covers specialization education in health area, in-service training and initiation training at work.

\section{Material and methods}

\section{Material}

Literature research was made from five universities (University of Helsinki [22], University of Tampere [23], University of Turku [24], University of Eastern Finland [25], University of Oulu [26], nine universities of applied sciences (Metropolia [27], Savonia [28], Laurea [29], Lahti [30], Satakunta [31], Tampere [32], Diakonia [33], Oulu [34] and Turku University of Applied Sciences [35] and the practical nurse education in Tampere Adult Education Centre TAKK [36], Jyväskylä Institute of Adult Education [37], and Stadin ammattiopisto in Helsinki [38]. In addition to a few known supplementary education organizers, continuing education were sought via Google. In this literature search, there were four organizations which provided continuing education for the health care personnel covering education given by the labor unions, external companies and the universities of applied sciences.

Along with the literature search, there were interviews of the health care professionals. There were 24 theme interviews that were done via telephone during December 2016. The median age of the interviewees was 31 years (average of 34). All the interviewees were female. Most of the participants came from the Pirkanmaa region (13), then southern Finland (5) and the rest form the eastern and northern Finland. Among the interviewees there were six practical nurses, 10 with nursing education (registered nurse and/or public health nurse), a biomedical laboratory technologist, a bachelor of social sciences, an occupational therapist and a pharmacist. There were also six medical doctors or students of medicine. Three of the interviewees had several educations and interviewees may have been a with a student status at the time of the interview. The median of the years after the graduation of the already 
graduated interviewees was six years (average 10 years).

\section{Methodology}

In the literature research all the curricula in relevant fields and schools, universities and companies were searched through from the study guides of the organization. Search includes only obligatory courses from curricula of the year 2017 from the nursing and medical doctors' education. Practical nursing and supplementary education survey was made during December 2016 and covers teaching during year 2016-2017. The study guides usually reveal the contents of a course and its extent in ECTS credits (cr) or in hours.

The future of the nursing education -project stated the minimum requirements of the general nursing education according to the recognition of Professional Qualifications and Regulation (EY/55/2013) [17,39]. From the IT perspective different themes rise from the guidelines which are embedded under different categories of the recommendation. The physician and nursing curricula are evaluated under the following specific themes:

- Basic IT skills (added widened theme): Data search (original theme, from most common health science databases) use of email, internet browser, presentations, word processing

- Information confidentiality and security: risks, data protection plan, information systems, confidentiality in the treatment process, patient's right to access own medical records

- Documentation: applying structurally coherent and nationally standardized classification, documentation as a part of the decision making process in nursing

- Patient record systems: use of patient record systems

- Use of technology in patient care: The use of care and monitoring equipment

- Information and communications technologies: use in education and communication

- eHealth services: utilization of electronic services as a part of treatment
- Social media: utilization of social media in nursing

The interview consisted of background information questions and nine questions concerning the health IT education throughout their career. The questions can be found in the Annex A. Often the questions engendered discussion, which revealed the experiences and attitudes of the interviewees towards health IT in general, too.

\section{Results}

\section{Literature research \\ Education of medical doctors at Universities}

It is typical that the medical education does not contain separate IT skills courses. The IT skills are often included together with other material related to administration or medicine. There were no education in information and communications technology in education, eHealth services nor Social media.

University of Helsinki teaches basic IT skills and IT security in a compulsory $1.5 \mathrm{cr}$ course and in a voluntary 1.5 cr course. Basic IT skills are also applied at least in two other courses. Patient record systems are introduced in a $1.5 \mathrm{cr}$ primary health care course. Documentation is a part of three medical courses and medical technology is a part of six medical courses. [22]

University of Tampere teaches basic IT skills in the introduction to medical studies ( $4 \mathrm{cr}$ ) course but basic IT skills are a part of or needed in two other courses, too. Education about documentation is given as a part of two medical courses. [23]

University of Turku covers basic IT skills in the information search course (0-3 cr) and in the Swedish language course. Information security is touched in two courses, which also contain information about patient record systems. Documentation skills are developed as a part of five courses. At least seven courses contain skills in the application of medical technology. [24] 
Basic IT skills get developed as a part of three generic type of courses in the University of Eastern Finland. Patient record systems are a part of the patient examination course of internal medicine. The same course contains also documentation information, which is also offered in the patient examination course. Six courses, like the course of isotope medicine touch medical technology topics, too. [25]

University of Oulu has some basic IT material in the three medical courses. The patient interview and examination course includes documentation. The radiology courses and another medical content course apply medical technology. [26]

\section{Registered nursing education}

None of the registered nurse education organizations in this study offered education in all the themes suggested in the future of the nursing education recommendation. Like in the physician education, the IT skills were often a part of another course, which made it somewhat difficult to see how much of the course actually contained IT education.

Basic IT skills appeared to belong to the nurse education of every education organization surveyed. They were usually embedded to the orientation course to nursing studies but the application of the basic IT skills was necessary in various other courses, as well.

Traces of educational content of information confidentiality and security were found in the curricula of five of the nine education organizations. In some of these curricula, the security related issues were a part of the basic IT skills but this topic was clearly not much emphasized in the published curricula.

Patient record systems were covered only in two of the nine surveyed curricula. This suggests that the educational organizations had outsourced this topic to the training sites of the future nurses because they need to use the record systems in their daily work during the training.
Documentation was much better covered in the curricula. Only one published curriculum did not include documentation to the descriptions of any of the compulsory courses of the registered nurse degree.

Five out of nine educational organizations had included patient guidance in using electronic health resources to their curricula. This content was systematically included to the education of the guidance of the patients in general.

Education about eHealth services was offered in six out of nine curricula. This education appeared to be included in quite various courses ranging from professional development to customer guidance and training without any clear line.

The use of social media in health care was only introduced in three of the nine surveyed curricula. In two of them, the topic was a part of the evidence based nursing education and in one it was a part of customer guidance.

The use of medical technology was also covered by all educational organizations. This education seemed to be included to the core nursing courses. Only in one case the phrase "wellfare technology" appeared in the course name. In practically all other cases the content was embedded in the course which was called nursing in something.

\section{Practical nursing education}

The content of the education of the practical nurses is defined in detail by the Finnish National Board of Education [18]. Education of the practical nurses is divided into the basic studies of the vocational education and to profession specific courses. There are different study programs that a practical nurse can specialize in: Care for the Disabled, Care for the Elderly, Children's and Youth Care and Education, Chiropody, Customer Services and Information Management, Emergency Care, Mental Health and Substance Abuse Welfare Work, Nursing and Care, Oral and Dental Care and Rehabilitation. $[18,42]$. In the common obligatory part of the studies there is a study module under the skills of 
mathematical and natural science knowledge called the Computer and information technology and how to benefit from it. This study module is $1 / 180$ study credit of the whole degree. Obligatory study goals include that the student is able to use the most common computer and information applications and knows how to store and send data. Goals also include the student's skills to protect one's privacy in the internet and how to comply with data and information protection instructions as well as copyright regulations. There are also voluntary goals for learning. These goals include the professional use of the software that is used in the field, the start of using new software and appliances, to use the electronic media and to use digital material in job search. [18]

Tampere Adult Education Centre (TAKK) gives practical nursing education as a competence based education. For every student there will be a personal study plan made based on their previous education and work experience. The basic education of the degree, including IT skills, is integrated into the other parts of the study. If a student has problems with basic IT skills, she/he will have personal or group education to learn the needed IT skill for studying. TAKK has all the study material online at a Moodle learning portal. Profession specific training for IT is mostly learned in practice training, which is about half of the education, because different hospitals and care places have different software applications. For documentation and structured documentation there are lessons at school where, for example, patient cases are used for students to solve. In these lessons, students learn how to do documentation (style, structure, headlines, what is essential etc.) [36]

Stadin ammattiopisto and Jyväskylä Institute of Adult Education also give education in practical nursing. The content of the education is quite the same as in other vocational institutes, and follows the guidelines stated by the Finnish National Board of Education, but for example, the study guide of Stadin ammattiopisto has defined more clearly that there is education on structured documentation and Kanta-archive, and education on pharmaceutical databases. Jyväskylä Institute of Adult Education, on the other hand, provides practical training on documentation with the Effica health record system and for ePrescription already at school. [37,38]

\section{Supplementary education}

The literature survey of supplementary education was made during December 2016 -January 2017. This education usually consists of courses with typically a narrow scope theme and a duration of 1-2 days. These courses vary considerably and the offering can be quite different from year to year.

In this literature survey, we found six organizations giving supplementary education in health IT related topics. As participation in supplementary education is compulsory for health professionals, it is probable that more organizations such as the universities of applied sciences organize supplementary education courses containing health IT related material, as well, but information about all these courses is not available around the year. Therefore, the following courses and their organizers can be shown as examples.

Fioca - Finnish Nurses Association, provided a two-day course organized together with the Diabetes Association Finland. The course contained information on how to take care of diabetes as a professional and included also a part about how digitalization changes the care from the patient's perspective. Fioca also provided a two-day course on HaiPro, which is a digital system for reporting safety incidents in health care organizations. [40]

Tehy -The Union of Health and Social Care Professionals, had a two-day course on updating the social media and information technology skills. The course contained teaching in Microsoft Office 365 -software and social media applications in work use (e.g LinkedIn). Law and data security aspects were also covered. [41] The labor union Super for practical nurses did not offer any health IT supplementary education at the moment. [42]

Tampere University of Applied Sciences had supplementary education on structured documentation (8 h). The course contained information on structured documentation in detail as well as safety risks. There was also a course on International Classification of Functioning, Disability and Health (ICF) and Technologies (14 h). 
One part of the course is about the technologies in the future digitalized society. [43]

Turku University of Applied Sciences provides two supplementary education courses. Those content and duration is to be decided with the employer organization. The courses are about information search and sturctured documentation. [44]

Metropolia University of Applied Sciences has a course for non-Finnish health care personnel (3h) for developing their skills in documentation. The documentation course was provided, but the exact content were not yet available. [45]

Professio is a company providing supplementary education. During the year 2016 they provided seven health IT related courses. Professio provided courses on digitalization related to the ongoing social and health care reform in Finland. There was a course on digitalization and Social Welfare and Health Care Reform (2 days), digital strategy for the reform in the public and the private sectors ( 2 days), Internet of things and the reform (including the aspects of information and data security and biobanks as well as service and business models) ( 2 days), and a course on the reform and information security (2 days). Unrelated to the reform Professio offered also the courses Remote and internet counselling in mental health care ( 2 days), remote appointments and digitalization in health care ( 2 days) and electronic care assessment (2 days). [46]

\section{Interviews}

In the following, the answers to the interview questions to the health professionals are summarized. The three professional groups are handled separately or as a single group when appropriate.

\section{How was health IT taught in your university/school?}

Medical doctors or the students of medicine have had a little or not at all education for IT. There has been training for patient record systems and documentation in practice training or as a lecture. Two out of six had had training for information search in the research methods course. One university provided a basic course of IT if a student felt he/she needed it and one university for all of the students. The interviewees had had teaching about patient record systems mostly during their training periods in the hospitals by their instructors.

Table 1 presents how IT was educated to medical doctors, to registered nurses and others at the bachelor's level and to practical nurses. Patient records were trained usually in the practical training periods in the hospitals by the instructors.

Table 1. Health IT related education of the interviewees during their degree studies.

\begin{tabular}{lllllll}
\hline & $\begin{array}{l}\text { Basic } \\
\text { skills }\end{array}$ & $\begin{array}{l}\text { IT } \\
\text { cessing }\end{array}$ & $\begin{array}{l}\text { Word pro- } \\
\text { cystems }\end{array}$ & $\begin{array}{l}\text { Information } \\
\text { systures }\end{array}$ & $\begin{array}{l}\text { on } \\
\text { documentation }\end{array}$ & $\begin{array}{l}\text { No } \text { ICT at the } \\
\text { time of studying }\end{array}$ \\
\hline Medical doctors $(\mathrm{N}=6)$ & 1 & 0 & 6 & 1 & 0 \\
Bachelor's degree $(\mathrm{N}=14)$ & 5 & 10 & 9 & 1 & 2 \\
Practical nurse $(\mathrm{N}=4)$ & 1 & 3 & 2 & 0 & 0 \\
\hline
\end{tabular}


Do you happen to know if some other university/school has better situation in health IT education offering than your own school?

The interviewees did not know the situation in other schools. One of the interviewees thought that the education might be better at this moment than it had been before.

\section{How were you inducted to the IT system of your work place?}

Medical doctors were all (6) inducted to the IT system when they have started in their working place. Four of the six respondents got 1-3 hours of training or education, one respondent had a two-day training to the patient record system once in the beginning. Still, one respondent answered that she had been in a working place where no introductory training was given at all.

Seven of the 14 participants with a bachelor's degree had had education or lectures about information systems used at the working place. Seven of the 14 answered having obtained training from colleagues. Some were instructed by colleagues during their training period of their studies. One answered that there was no training to any employee even though the whole ITsystem of the hospital pharmacy was changed. One answered also that she did not receive any health IT education at all. One respondent answered that she had to study the health record system in her own free time.

Most of the practical nurses had had training for IT from the instructors of the practical training and all from other colleagues. One answered that a worker must be responsible herself that she has the needed IT skills for the work. One practical nurse answered that there was no electronic documentation yet at her working place. One employee organization provided documentation education and training of the health record systems.

\section{What kind of in house training you've had at your working place about IT?}

Four out of six medical doctors answered that there had been some in house IT training at their working place. Changes in the IT systems had sometimes been discussed in (doctor) meetings in five of the six cases. Four answered that there had been emails informing the staff about the changes in IT systems.

Nine of the employees with bachelor's degree answered that they had had education for IT during their career. The education had been, for example, lectures about the changes in the health record system, word processing or about some other programs used in that health care unit. Five of the respondents answered also that they had not received any kind of education for IT at their working places. The changes in the IT systems had also been notified by email in half of the cases.

Three of the four practical nurses, answered having had some kind of education for IT at their working places. The education had contained, for example, showing how a new system works and lectures. The workers had also learned to use the systems themselves. One practical nurse answered that there had been no training for substitutes but for permanent workers there had been a short course about the health record system and one nurse answered that there had been no training at all. One respondent answered that there had been emails notifying about changes in the systems.

\section{What kind of in-service education relating to health IT have you had at your working place?}

21 of the participants answered that there had not been any in-service education for employees at their working place. One of the participants answered that there have been opportunities but people did not necessarily participate in those. The lack of participation might have been caused by the fact that there had not been time for education or that they had not been interested in taking part in extra education. The respondents thought that there had been a lot of IT support available. One of the participants answered that 
there had been no extra education for substitutes, but there had been some supplementary education for permanent workers. One of the participants answered that there had been some short education sessions where a colleague who had better knowledge trained the others.

\section{Have you been in specialization education? Has there been health IT training?}

Six of the participants had been or were in specialization training (in nursing or in medicine) at the moment. In neither of those educations, there had been any health IT education. Only at the University of Tampere education was provided if the person had not accomplished basic IT education before, for example, at the bachelor's degree education.

\section{What kind of needs of health IT education are there in your profession?}

Four out of six medical doctors answered that there should be more training for information systems and three out of six mentioned that there should be a good introductory training at the beginning of the use of a new system. There should preferably be a rehearsal training after the start of the system. One of the respondents answered that the digitalization had not yet succeeded in her work place because many colleagues do not have full understanding about the systems. There had also been resistance against using and learning digital productivity tools. Even emails had not been used efficiently. The responder said that the use of the IT systems should be spread but that also the usability should improve.

Ten of the fourteen professionals with a bachelor's degree wanted more education in information systems or in documentation. Three out of fourteen wanted more education in word processing or other basic IT skills. Some responders thought that they had often been left alone to learn the use of new software versions and their functions. This had been time- consuming and the full potential of the systems had not been exploited.

Two practical nurses answered that there should be a good introductory training to the IT systems in the beginning of the work. One suggested that training should be more concrete, for example teach hands-on real work cases. One answered that there is no need at the moment.

\section{Do you think that you've had enough training in health IT? What areas need more training?}

Ten respondents answered that they had had enough training in IT. Still, six out of ten thought that they "survive", i.e. they have only the minimum of the required skills or they know the basic skills to do the daily work. Three of the participants answered that they would like to have more training, one about the health records and basic IT-skills, one about PACS systems and one about referral policies. One respondent told that in general, there is lack of education. Two participants answered yes/no or it varies. They also thought that they have survived or have the basic skills.

Twelve respondents answered that they have not received enough education in IT. Five wanted more education in basic skills or word processing. Eight respondents wanted more education for information systems or software used at the hospital. One respondent said that some things have to be learned by themselves and that she had learned some functionalities of the software even by coincidence. One respondent answered that it is difficult for her to participate in the education because she is at part-time pension. It was also mentioned that surprising situations are difficult to handle if there is no knowledge how to act (in the ICT perspective). Doctors might also call nurses if they didn't know how the systems work. There might not be any education for substitutes. 
Who should be responsible for the health IT education?

All the interviewees answered that the health IT education should be provided by the employer. The employee should have the basic skills and know what needs there are in the education and look for that knowledge.

\section{Discussion}

The literature review covered all the universities giving physician education, nine of the 23 universities of applied sciences [17] giving registered nurse education and three schools for practical nurse education. We believe that the covered universities of applied sciences are representative enough about the level of health IT education given to the health care personnel because the covered organizations were large and they were located in the large cities in Finland. The practical nursing education is most tightly controlled by the national plans of the ministry, so the local variations were expected to be small. Therefore, one organization is covered more thoroughly and the two others were compared with that one and with the national guideline.

The literature review of the study guides of the educational organizations revealed that there is quite a lot of variety in the health IT education. Registered nursing education appeared to contain more IT related education than the phycisians' education. The national recommendation of 2015 had not been implemented fully to the curricula yet. This means that the educational organizations may still need support in putting the recommendations into practice. We don't know if the educators themselves are well enough prepared for this. The good result was that the basic IT skills were a part of the education in all organizations. The basic IT course did not necessarily consist all the basic IT skills listed in this paper, data search was the most common theme found.

The number of professionals interviewed was not very large but the time limitation did not allow us to conduct more interviews. However, we believe that the number was sufficient to give an impression about the way how the health professionals experience the health IT education in Finland in general. Interviewing many individuals who have passed the same program in the same educational organization would not have brought much new information to the questions we wanted answers for.

The previous study of IT education of the health care personnel made in the UK in the year 2004 [7] indicated the need of additional education. The situation seemed to be fairly similar in Finland in 2016-2017 although some educational institutions seemed to have included the use of IT to other subjects, too. They had recognized the role of the increasing use of IT systems better than others. The quality of health and social services was generally considered as an important theme and the information security was emphasized but privacy and security did not play a sufficiently significant role in the education

Many of the interviewees in our study thought that they "survive" with the IT-skills they have. Expressing the views in this way indicates that there is potential to use the IT systems more efficiently if the skills were better. Health care personnel seemed to have the basic knowledge of the patient record systems but they often thought that they want to have more education to use the programs. Many people were willing to learn new and more efficient ways to use the programs, and in this study no one answered directly not being interested in health IT education. Some interviewees mentioned that the lack of motivation was observable in the schools and universities providing education for health care personnel and at working places.

As IT is the key element in the health care processes today, it would be beneficial to the worker and employer and to the society, to use the IT in the most efficient way. It is a tool for supporting the work, not an opponent demanding a large part of the work time although the experiences expressed in the interviews sometimes painted in this picture.

Despite the recommendations of IMIA and others, it has been difficult to introduce more IT related topics to the health professional education. One of the reasons is 
that although the need for IT skills is often recognized, it is hard to make room to IT education in the curricula because it would mean cuts in other, more traditional subject areas of the education. However, at this day and age when the use of computers is daily in many health professions, it is not acceptable that the students can include no or very little IT education in their basic degree. Many times the students are taught by other workers to the health record systems while they are in their training which is part of the basic education. The national recommendation of 2015 [17] is a move to the right direction.

The interviewed health care professionals answered in the questionnaire that the education of the necessary IT-skills should be covered by the employer. This suggests that there is only a little market for health IT education products, which should be paid by the students themselves. Even free of charge material might not be used vary much because there are not enough incentives to spend one's free time to health IT education.

Usually there is an annual budget for education for the graduated personnel in health care organizations. Access to education is still not guaranteed in this way because IT is not the only subject where the personnel requires continuing education. Even though the education would be free of charge, it is possible that the employee is not allocated time to participate in that.

The interviews raised again the issue that there are also usability issues that cannot be solved by training the employees. This is consistent with the study made in the year 2014 about the usability of the electronic health record systems from the phycisians' perspective [47]. The software application user interfaces should be planned for each user group separately so that they are intuitive to the job roles. The programs don't always communicate with each other. Even though the aim of the use of the programs are the same, the practical use can be very different. Ideally, the software applications would be so intuitive so that there would be no need for education. This would be especially beneficial in the frequent situations when a replacement is called in to take care of the work of a permanent employee on a sudden sick leave.
The health care professionals begin their careers often as substitutes. The substitutes are trained even less in IT use than the regular staff at the work place. Therefore, all graduates need the health IT system user skills to be part of their basic education.

Health IT education can be divided into two main domains. There are the basic IT skills and on the other hand, profession specific skills which are taught at the schools and universities. These profession specific skills include (structured) documentation and the use of some specific information system. Progressive health IT system producers could make their software remotely available as training material to educational institutions and simultaneously collect feedback to improve their products.

Many interviewees hoped that there would be first education about the basic skills and then a rehearsal education about the "tricks" how to get a deeper understanding about the specific application they use at work. Often this deepening part is not, however, implemented. The suggested cycle for the basic skills of health IT education at work places could be:

- Introduction to the health IT programs used at the current working place at the beginning of the work with the possibility to try the software applications in action

- Rehearsal about the health software used at the working place and a possibility to ask questions after about 1-3 months after the first education

- Updating the education once in 6-12 months, keeping up with the updates

The employer might get more output of its employees if the IT education of the employees were better planned. This requires that sufficient time is allocated to the education. An evaluation of the basic IT skills of the employee could help in planning the education better by identifying the gaps in the skills relevant to the work.

A lot of learning happens by the personnel themselves or with the help of colleagues. The next level of education is when one of the personnel goes to an education 
lecture and then acts as a teacher to the other colleagues at the ward. There are also people who are responsible, for example, some part of the program, and keep up with the new knowledge of the software and then teach and act as support people at the ward to others. Larger organizations have more education available to their workers. For example, the City of Helsinki, has an education center to train the workers. Still, the education and IT skills may vary among workers even inside a larger organization.

\section{Conclusion}

Different roles in the health care demand different operations to be done with the IT. For example laboratory workers, pharmacists and nurses use different programs in their basic work. For this reason each group requires somewhat different education, too. Education to the specific software applications should be given in that working place. A two- or three-phase education was often suggested containing the basics of a new application first, the information about the more advanced features of the application after a few weeks of normal use of the application and a rehearsal and new feature introduction 6-12 months after the first training.

All the software applications that are used for the same purpose differ from each other, so the use of all of them cannot be educated at the schools and universities. Thus, the education of the use of the applications was considered more like working place specific knowledge, not as a part of the basic education given at schools or universities. This is challenging in trying to provide European-wide common educational content for the health IT field.

This study was an eye opener for the development of educational improvements to the health care work force. The reality in the field is far from the ideals of the IMIA recommendations or the wealth of possible health IT competencies in the HITCOMP data base. Certain minimal health IT learning outcomes should be imposed on the organizations providing degree education, perhaps controlled by a passed national exam before the professional is entered to the health care professional data base. This would be comparable to the exam which needs to be passed before getting the permission to deliver drugs to the patients.

For the existing health care work force, the allocation of sufficient time for continuing education by the employer is necessary in the work force health IT skills development which comes back to the employer as increased productivity. IT education competes about the time of the health care personnel with the daily work and other continuing education. The IT education serves the professional's needs best if it is time efficient and helps in the problems encountered at the work place.

\section{Acknowledgements}

This study has been performed with the European Commission Grant \#727552 Horizon 2020 - Societal Challenge: Healthcare Workforce IT Skills - SC1-HC0132016.

\section{Conflict of interest statement}

The authors have no conflicts of interests with the producers of the equipment or producers of the data used in this study.

\section{References}

[1] Värri A, Blake R, Roberts J, Fenton S, Cleary M, Zacks S, Datta G, Kaye R, Parker J, Nguyen C, Dougherty M, Barry N, Cunningham F. Transatlantic collection of health informatics competencies. Finnish Journal of eHealth and eWelfare 2016;8(2-3):127-136.

[2] Hasman A, Mantas J, Zarubina T. An Abridged History of Medical Informatics Education in Europe. Acta Inform Med. $2014 \quad$ Feb;22(1):25-36. https://doi.org/10.5455/aim.2014.22.25-36

[3] Hasman A, Sosa M. Education and training of health informatics. In Hasman A, Albert A, Wainwright $P$, Klar 
R, Sosa M. (Eds.) Europe in Education and Training in Health Informatics. IOS Press; 1995. p. 13-24.

[4] Hasman A. Education and training in health informatics: the IT-EDUCTRA project. Int J Med Inform. 1998;50:179-185. https://doi.org/10.1016/S13865056(98)00066-5

[5] Hasman A, Albert A. Education and training in health informatics: guidelines for European curricula. Int J Med Inform 1997 Jun;45(1-2):91-110. https://doi.org/10.1016/S1386-5056(97)00039-7

[6] Mantas J. 1998. NIGHTINGALE-a new perspective in nursing informatics education in Europe. Stud Health Technol Inform. 1998;51:102-113.

[7] Murphy J, Stramer K, Clamp S, Grubb P, Gosland J, Davis $\mathrm{S}$. Health informatics education for clinicians and managers-What's holding up progress? Int J Med Inform. $2004 \quad$ Mar 18;73(2):205-13 https://doi.org/10.1016/j.ijmedinf.2003.12.003

[8] National Health Service (NHS) in England. Learning to Manage Health Information- a theme for clinical education 2012. Embedding Informatics into Clinical Education project [Internet]. 2012 [cited 2017 Jan 13]. Available from: http://www.eiceresources.org/images/ learningtomanage_12.pdf

[9] Mantas J, Ammenwerth E, Demiris G, Hasman A, Haux R, Hersh W, Hovenga E, Lun KC, Marin H, MartinSanchez F, Wright G. IMIA Recommendations on Education Task Force. Recommendations of the International Medical Informatics Association (IMIA) on Education in Biomedical and Health Informatics. First Revision. Methods Inf Med. 2010 Jan 7;49(2):105-120. https://doi.org/10.3414/ME5119

[10] University of Eastern Finland. Sosiaali- ja terveydenhuollon tietohallinto [Internet]. 2017 [cited 2017 Jan 13]. Available from: https://www.uef.fi/web/ sosiaali-ja-terveysjohtaminen/sosiaali-jaterveydenhuollon-tietohallinto

[11] EU*US eHealth Work project web site [Internet]. 2017 [cited 2017 Jan 10]. Available from: http://ehealthwork.com/index.html.
[12] Health information technology competencies' database [Internet]. 2017 [cited 2017 Jan 10]. Available from: http://hitcomp.siframework.org/.

[13] Finlex. Valtioneuvoston asetus ammattikorkeakouluista [Internet]. 1129/2014. Available (accessed on 13.1.2017): http://www.finlex.fi/fi/laki/alkup/2014/ 20141129

[14] Ministry of Education and Culture (OKM). Ammattikorkeakoulujen koulutusvastuut tutkinnoittain [Internet]. 2015 [cited 2017 Jan 13]. Available: http://www.minedu.fi/export/sites/default/OPM/Koulu tus/ammattikorkeakoulutus/ammattikorkeakoulut/Liitt eet/amk_koulutusvastuut_tutkinnoittain_11092015.pdf

[15] Finlex. Laki terveydenhuollon ammattihenkilöistä [Internet]. 28.6.1994/559. 1994 [cited 2017 Jan 13]. Available from: http://www.finlex.fi/fi/laki/ajantasa/ 1994/19940559

[16] Finlex. Yliopistolaki [Internet]. 24.7.2009/558. 2009 [cited 2017 Jan 13]. Available from: http://www.finlex.fi/fi/laki/ajantasa/2009/20090558\#L 2P7

[17] Ammattikorkeakoulujen terveysalan verkosto \& Suomen sairaanhoitajaliitto ry. Sairaanhoitajan ammatillinen osaaminen - Sairaanhoitajakoulutuksen tulevaisuus -hanke [Internet]. 2015 [cited 2017 Apr 2]. Available from: https://sairaanhoitajat.fi/wpcontent/uploads/2015/09/Sairaanhoitajanammatillinen-osaaminen.pdf

[18] Finnish National Board of Education (Opetushallitus).Ammatillisen perustutkinnon perusteet. Sosiaali- ja terveysalan perustutkinto, lähihoitaja 2014. Määräys 79/011/2014 [Internet]. 2014 [cited 2017 Jan 8]. Available from: http://www.oph.fi/download/ 162460_sosiaali_ja_terveysalan_pt_01082015.pdf

[19] National Supervisory Authority for Welfare and Health in Finland, Valvira [Internet]. 2017 cited 2017 Jan 10]. Available from: http://www.valvira.fi/ web/en/front-page

[20] Super [Internet]. 2017 [cited 2017 Jan 13]. Available from: https://www.superliitto.fi/tyoelamassa/ taydennyskoulutus/ 
[21] Sosiaali- ja terveysministeriö [Internet]. 2017 [cited 2017 Jan 13]. Available from: http://stm.fi/ sotehenkilosto/taydennyskoulutus

[22] University of Helsinki. Study Guide [Internet]. 2017 [cited 2017 Mar 30]. Available (accessed on 30.3.2017): https://weboodi.helsinki.fi/hy/vl_kehys.jsp?Kieli=1\&MD 5avain $=\& v 1$ tila $=4 \& O p a s=4847 \&$ Org $=1000000836 \&$ Koh tTyypHierAuk=2

[23] University of Tampere. Study Guide [Internet]. 2017 [cited 2017 Mar 30]. Available from: https://www10.uta.fi/opas/tutkintoOhjelma.htm?rid=1 0152\&uiLang=fi\&lang=fi\&lvv=2015

[24] University of Turku. Study Guide [Internet]. 2017 [cited 2017 Mar 30]. Available (accessed on 30.3.2017): https://nettiopsu.utu.fi/opas/tutkintoOhjelma.htm?rid =30512\&uilang=fi\&lang=fi\&lvv=2016

[25] University of Eastern Finland. Study Guide [Internet]. 2017 [cited 2017 Mar 30]. Available from: https://weboodi.uef.fi/weboodi/vl_kehys.jsp?Kieli=1\& MD5avain $=\& v 1$ tila $=4 \& O$ pas $=3335 \&$ Org $=20784102 \&$ Ko htTyypHierAuk=41

[26] University of Oulu. Study Guide [Internet]. 2017 [cited 2017 Mar 30]. Available from: https://weboodi.oulu.fi/oodi/vl_kehys.jsp?Kieli=1\&MD 5avain $=\& v 1$ tila $=4 \&$ Opas $=1670 \& O r g=41624920 \&$ KohtTy ypHierSulj=2

[27] Metropolia University of Applied Sciences [Internet]. 2017 [cited 2017 Mar 30]. Available from: http://opinto-opas-ops.metropolia.fi/index.php/fi/ 88094/fi/70320/SX017S1/year/2017

[28] Savonia University of Applied Sciences [Internet]. Study guide. 2017 [cited 2017 Mar 30]. Available from: http://portal.savonia.fi/amk/fi/opiskelijalle/opetussuun nitelmat?yks=KS\&krtid $=1093 \&$ tab $=6$

[29] Laurea University of Applied Sciences. Study guide [Internet]. 2017 [cited 2017 Mar 30]. Available from: https://soleops.laurea.fi/opsnet/disp/fi/ops_KoulOhjOp s/tab/tab/sea?ryhma_id=16581783\&koulohj_id=10040 416\&stack=push

[30] Lahti University of Applied Sciences. Study guide [Internet]. 2017 [cited 2017 Mar 30]. Available from: http://opinto-opas.lamk.fi/index.php/fi/68177/fi/ 68147/STSH17/year/2017

[31] Satakunta University of Applied Sciences. Study guide [Internet]. 2017 [cited 2017 Mar 30]. Available from: https://samk.solenovo.fi/opsnet/disp/fi/ ops_KoulOhjOps/tab/tab/sea?ryhma_id=14584963\&ko ulohj_id=2300554\&valkiel=fi\&stack=push

[32] Tampere University of Applied Sciences. Study Guide [Internet]. 2017 [cited 2017 Mar 30]. Available from: http://opinto-opas-ops.tamk.fi/index.php/fi/167/ fi/49595/16SH/year/2017

[32] Tampere University of Applied Sciences. Study guide [Internet]. 2017 [cited 2017 Mar 31]. Available from: http://www.tamk.fi/web/tamk/terveys-jasosiaalipalvelut-taydennyskoulutus

[33] Diakonia University of Applied Sciences. Study guide [Internet]. 2017 [cited 2017 Mar 30]. Available from: https://soleops.diak.fi/opsnet/disp/fi/ ops_KoulOhjOps/tab/tab/sea?ryhma_id=4327705\&koul ohj_id=3188592\&valkiel=fi\&stack=push

[34] Oulu University of Applied Sciences. Study guide [Internet]. 2017 [cited 2017 Mar 30]. Available from: http://www.oamk.fi/opinto-opas/koulutusohjelmat/ ?koulutus=sai2017sp\&lk=s2017

[35] Turku University of Applied Sciences. Study Guide [Internet]. 2017 [cited 2017 Mar 30]. Available from: https://ops.turkuamk.fi/opsnet/disp/fi/ops_KoulOhjOp s/tab/tab/sea?ryhma_id=20579417\&koulohj_id=83571 $34 \&$ valkiel=fi\&stack=push

[36] Tampereen aikuiskoulutuskeskus (TAKK) [Internet]. 2017 [cited 2017 Jan 13]. Available from: http://www.takk.fi/opiskelijalle/opiskelijan_opas.html

[37] Jyväskylä Institute of Adult Education [Internet]. 2017 [cited 2017 Jan 11]. Available: https://www.jao.fi/en/Education/Jyvaskyla-Institute-ofAdult-Education

[38] Stadin ammattiopisto [Internet], 2017 [cited 2017 Jan 11]. Available: http://www.hel.fi/www/ ammatillinen/fi/opiskelijalle/

[39] European Union. Directive 2013/55/EU of the European parliament and of the council [Internet]. 2013 
[cited 2017 Jan 12]. Available from: http://eurlex.europa.eu/legal-content/EN/ALL/?uri=celex\%

3A32013L0055

[40] Fioca [Internet]. 2017 [cited 2017 Jan 11]. Available from: https://diabetesosaaja.fi/

[41] Tehy [Internet]. 2017 [cited 2017 Jan 12]. Available from: https://www.tehy.fi/fi/palvelut-ja-edut/ tapahtumat

[42] Super [Internet]. 2017 [cited 2017 Jan 8]. Available from: https://www.superliitto.fi/in-english/practicalnurse-training/

[43] Tampere University of Applied Sciences [Internet]. 2017 [cited 2017 Jan 8]. Available from: http://www.tamk.fi/web/tamk/terveys-jasosiaalipalvelut-taydennyskoulutus

[44] Turku University of Applied Sciences [Internet]. 2017 [cited 2017 Jan 8]. Available from: http://www.turkuamk.fi/fi/tyoelamapalvelut/koulutush aku/\#!category=15\&sort=1

[45] Metropolia University of applied Sciences [Internet]. 2017 [cited 2017 Jan 8]. Available from: http://www.metropolia.fi/koulutukset/taydennyskoulut us/sosiaali-ja-terveysala/

[46] Professio [Internet]. 2017 [cited 2017 Jan 11]. Available from: http://ilmoittaudu.professio.fi/ tapahtumat/professio/

[47] Vänskä J, Vainiomäki S, Kaipio J, Hyppönen H, Reponen J, Lääveri T. Potilastietojärjestelmät lääkärin välineenä 2014: käyttäjäkokemuksissa ei merkittäviä muutoksia. Terveydenhuoltotutkimus. Suomen Lääkärilehti [Internet]. 2014 [cited 2017 Jan 11];49. Available from: https://www.slideshare.net/laakariliitto/sll4920144-3351

\section{Appendix A.}

\section{Theme interview questions:}

1. Background information questions:

- name, age, city

- degree, university, year of graduation

- $\quad$ current work place, previous workplaces and job titles

2. How was health IT taught in your university/school?

3. Do you happen to know if some other university/school has better situation in health IT education offering than your own school?

4. How were you inducted to the IT system of your work place?

5. What kind of in house training you've had at your working place about IT?

6. What kind of in-service education relating to health IT have you had at your working place?

7. Have you been in specialization education? Has there been health IT training?

8. What kind of needs of health IT education there are in your profession?

9. Do you think that you've had enough training in health IT? What areas need more training?

10. Who should be responsible for the health IT education? 